\title{
Author Correction: Development and performance of prototype serologic and molecular tests for hepatitis delta infection
}

Kelly E. Coller, Emily K. Butler, Ka-Cheung Luk, Mary A. Rodgers, Michael Cassidy, Jeffrey Gersch, Anne L. McNamara, Mary C. Kuhns, George J. Dawson, Lazare Kaptue, Birgit Bremer, Heiner Wedemeyer \& Gavin A. Cloherty

Correction to: Scientific Reports https://doi.org/10.1038/s41598-018-20455-5, published online 01 February 2018

In this Article, the authors neglected to cite a previous paper. This reference is being added because it contains important information on how an RT-PCR analysis was performed. The reference is included below as Ref 1 and should be cited in the text as follows:

In Supplementary Table S4, in column 5 'Ref', all instances of reference 35 should instead refer to this omitted reference.

In addition, in the Table legend of Supplementary Table S4:

"Primers and cycling conditions were previously described ${ }^{35 "}$

should read:

"Primers and cycling conditions were previously described"

\section{Reference}

1. Andernach, I. E. et al. Characterization of hepatitis delta virus in sub-Saharan Africa. Journal of clinical microbiology 52, 1629-1636, https://doi.org/10.1128/JCM.02297-13 (2014).

(i) Open Access This article is licensed under a Creative Commons Attribution 4.0 International License, which permits use, sharing, adaptation, distribution and reproduction in any medium or format, as long as you give appropriate credit to the original author(s) and the source, provide a link to the Creative Commons license, and indicate if changes were made. The images or other third party material in this article are included in the article's Creative Commons license, unless indicated otherwise in a credit line to the material. If material is not included in the article's Creative Commons license and your intended use is not permitted by statutory regulation or exceeds the permitted use, you will need to obtain permission directly from the copyright holder. To view a copy of this license, visit http://creativecommons.org/licenses/by/4.0/.

(c) The Author(s) 2020 